\title{
Focus group findings on clinicians' perceived barriers and facilitators to giving rights information to involuntary psychiatrics patients in British Columbia, Canada
}

\section{Iva W. Cheung ( $\square$ ivac@sfu.ca )}

Simon Fraser University https://orcid.org/0000-0002-8955-9382

Diego S. Silva

University of Sydney

Kimberly J. Miller

BC Children's Hospital Research Institute and Simon Fraser University

Erin E. Michalak

University of British Columbia

Charles H. Goldsmith

Simon Fraser University

\section{Research Article}

Keywords: mental health rights, independent rights advice, focus groups, thematic analysis, Theoretical Domains Framework, behaviour change techniques

Posted Date: November 30th, 2021

DOI: https://doi.org/10.21203/rs.3.rs-1120510/v1

License: (c) (i) This work is licensed under a Creative Commons Attribution 4.0 International License. Read Full License 


\section{Abstract \\ Background}

In British Columbia, Canada, clinicians are responsible for giving information about rights to patients involuntarily hospitalized under the Mental Health Act. But a survey commissioned by the Ministry of Health and an investigation by the $\mathrm{BC}$ Office of the Ombudsperson found that patients were not consistently receiving rights information.

\section{Methods}

Focus groups were used to probe clinicians' perceived barriers and facilitators to giving patients rights information. Focus group transcripts were thematically analyzed, and the themes were coded using the Theoretical Domains Framework to identify interventions that could encourage clinicians to consistently give patients complete rights information.

\section{Results}

Eighty-one psychiatric clinicians participated. Analysis identified these barriers: (a) clinicians receive inadequate training on the Mental Health Act and rights notification; (b) newly admitted patients might not be receptive to new information; (c) the tool used to communicate rights to patients is inadequate; (d) many patients don't speak English; (e) clinicians have competing priorities during the admission process; (f) clinicians face pressure from other staff to give incomplete information; $(\mathrm{g}$ ) the clinical workflow doesn't facilitate follow-up and accountability; and (h) staff don't receive enough support from their employer. The following facilitators were identified: (a) a team approach allows clinicians to share knowledge about the Mental Health Act and rights notification, (b) having one person take responsibility for rights information clarifies roles and increases accountability, (c) accreditation reminds clinicians of the importance of giving patients rights information, and (d) checklists remind clinicians of their rights-notification responsibilities.

\section{Conclusions}

These interventions may help clinicians give rights information more consistently: (a) training about the Mental Health Act and rights notification, (b) an accessible legal resource for clinicians and patients, (c) regular group sessions about rights for patients, (d) an improved rights-communication tool, in multiple languages, and (e) checklists, reminders, and accountability and feedback systems.

\section{Introduction}

Under British Columbia's (BC's) Mental Health Act, people who show signs of having a mental disorder may be detained and given treatment against their will if they meet the legal criteria for involuntary hospitalization. Between April 2020 and March 2021, the province saw 28,386 total involuntary admissions affecting almost 20,000 individuals [1]. 
Clinicians must advise involuntarily patients of their rights, using a statutory document known as Form 13, upon admission [2, 3]. These rights include:

- the right to know where they are and why they've been detained,

- the right to contact a lawyer,

- the right to challenge their detention-in court or by appealing to the Mental Health Review Board for a review panel hearing, and

- the right to request a second medical opinion on their treatment.

According to section 34 of the Mental Health Act, involuntary patients must be informed of their rights:

- when they are involuntarily admitted via Form 4 medical certificate,

- whenever they are transferred to a designated facility, and

- whenever their certification is renewed via a Form 6 renewal certificate.

If a patient appears not to understand the information, the legislation requires that they be given rights information again, as soon as they appear to have a greater capacity for understanding.

In BC, clinical staff-including nurses, social workers, and physicians-are typically assigned the task of giving patients rights information [4].

In addition to being a legal requirement, giving involuntary patients rights information can also have therapeutic effects: it can give patients a sense of procedural justice, which can reduce their feelings of coercion and engage them in their own care and recovery planning $[5,6]$.

However, in a survey published in $2011,43 \%$ of involuntary patients reported that they were not told their Mental Health Act rights in a way they could understand [7]. In 2019 the BC Office of the Ombudsperson reported on its investigation of the involuntary admission process, which found Form 13 in only $49 \%$ of involuntary patients' files, instead of the $100 \%$ as required by law. This finding suggested that clinicians were not fulfilling their duties under the Mental Health Act to give patients rights information and to document this interaction [8].

This paper presents focus group findings from clinicians about their perceived barriers and facilitators to consistently giving involuntary patients complete rights information upon admission. According to the Knowledgeto-Action Framework [9], understanding the barriers and facilitators of this behaviour can help decision makers within the mental health system tailor interventions to support and reinforce the behaviour. The findings from this study suggest several interventions that could help clinicians fulfill their legal and clinical duty to give involuntary patients information about their rights.

Patients' perspectives of the rights-information process have been presented elsewhere [10]. Understanding stakeholders' experiences of the rights-information process may help the province develop policies that both support involuntary patients' rights and respect clinicians' workflow in providing patient care, and this understanding may also inform policies in jurisdictions beyond BC.

\section{Methods}


Clinicians in Vancouver, BC, who give rights information to involuntary patients were invited to participate in an interactive educational session on the Mental Health Act that included a 15-minute focus group component. Five of these sessions were offered between 2019-05-24 (YYYY-MM-DD) and 2019-07-27, at three hospitals. Recruitment emails and posters, as well as the study consent form, informed participants that the study was being done as part of the first author's doctoral research. A full description of these sessions is available elsewhere [11].

For the focus group component of the session, participants were asked to discuss their answers to the following questions:

1. As clinicians, what do you think are the main barriers that get in the way of providing complete and consistent rights advice to involuntary patients?

2. What factors currently support you in providing rights advice to involuntary patients?

3. What suggestions do you have to improve the rights-advice process for clinicians and for patients?

The first author facilitated the discussion, which was audio recorded, while a research assistant (undergraduate- or master's-level) took notes. The first author transcribed the recordings verbatim and used the research assistant's notes both to confirm the accuracy of the transcript and to annotate it with participants' nonverbal communication.

The first author analyzed the transcript via thematic analysis shortly after each session [12]. Thematic analysis "is a method for identifying, analysing and reporting patterns (themes) within data" [12, p. 79]. It can be applied inductively or deductively to qualitative data and is not restricted to a particular theoretical framework.

In this study, the transcripts were analyzed inductively to identify themes without any particular framework but then coded to the domains within the Theoretical Domains Framework (TDF) [13]. The TDF "was developed by a collaboration of behavioural scientists and implementation researchers who identified theories relevant to implementation and grouped constructs from these theories into domains. The collaboration aimed to provide a comprehensive, theory-informed approach to identify determinants of behaviour" [14, p. 77]. In trying to encourage a specific target behaviour-in this case, consistently giving involuntary patients complete information about their Mental Health Act rights according to law-the TDF can help identify specific behavioural domains amenable to interventions that are likely to change clinician behaviour [15].

The first author used NVivo 12 [16] to track the themes within the transcripts and followed Braun and Clarke's [12] 15-point checklist for good thematic analysis. During this analysis, the first author reflexively considered her positionality as a female doctoral candidate with no clinical experience nor experience as an involuntary patient. Her approach to the data collection and analysis was informed not by lived experience but by her formal training in qualitative research methods and three years of interviewing experience.

The aim of the data collection was to reach thematic saturation, which was achieved after four sessions, with the data from the fifth session producing no new themes.

\section{Results}

Eighty-one clinicians, including nurses, social workers, occupational therapists, psychologists, dieticians, and pharmacists, participated over the five sessions of focus groups. Attendance at these sessions was not required, and therefore the sample of participants was self-selected. No participants had a prior relationship with the first 
author. Summary tables of the participants' professions and their years of clinical experience are available elsewhere [17].

Each participant was assigned a unique number identifier, consisting of the month and date of their training session and the order in which they joined on that day. For example, the participant labelled 05-24-16 attended the session held on May 24 and joined after participant 05-24-15. These identifiers are used in the supporting quotes that follow.

The themes from the discussions are grouped below into barriers, facilitators, and hypothetical facilitatorssolutions that participants proposed but that are not current facilitators. Their subthemes were coded to domains within the TDF. These themes, subthemes, and domains are summarized in the leftmost three columns of Table 1.

The dataset of anonymized focus group transcripts is available in the Federated Research Data Repository at https://doi.org/10.20383/102.0358.

\section{Barriers}

We identified several barriers clinicians faced that hindered them from consistently giving involuntary patients complete rights information.

\section{Clinicians receive inadequate training on the Mental Health Act generally and rights notification specifically}

This theme falls under the TDF domains of Knowledge, Skills, Social/Professional Role, and Beliefs about Capabilities (see Table 1).

Some clinicians felt they lacked the training to give complete and consistent rights information confidently (or "perceived competence" within the Beliefs about Capabilities domain). Several participants also expressed uncertainty about the process involved in helping patients exercise some of their legal rights. That is, although they knew they had to give rights information, many expressed a lack of process knowledge-that is, how to give rights information ("Knowledge" in the TDF). Some clinicians who work in units with slower patient turnover reported that the lack of opportunities to practise giving rights information contributed to their lower confidence:

07-17-08 (nurse): [There's] just no real formal training on the Mental Health Act. [...] So it's sort of like coming to an environment where you're doing more of the, like, education around that, like, first certification and just kind of trying to figure it out as you're going.

\section{***}

07-27-10 (nurse): On our inpatient units, we don't... we don't give the rights as much, and so the nurses would be even less familiar with, like, doing a Form 13, because it's only required there once per month, theoretically, whereas on our assessment unit, the flow of patients was much quicker through there, so they would be giving it more often. So I think, um, nurses on our inpatient units just don't have... like, it's not a priority because they are not as familiar with it. 
07-27-12 (nurse): I'm a psych nurse, personally, so, I mean, I'm familiar with Form 13, but some of the language is confusing. So if you're reading it, and you're just, like, "You have the right to appeal to a judge," and they're like, "How do I do that?" Or whatever it is, like, we might not be able to, like, articulate that, or even have the knowledge to be able to go beyond what's actually written. [...] Maybe you are just saying this verbatim, because you're, like, "Well, I know this is my job, I'm supposed to tell patients this," and then it's confusing to them and they're, like, "OK, well, now I have all this information, but I don't actually know how to access that."

$\star \star \star$

07-17-02 (nurse): Clinicians may not feel comfortable giving the rights because they might not feel comfortable with having the knowledge of what to do once they've given the right. So what's the next step when the client does say, "Well, I want to talk to a lawyer. I want to exercise my right to have a review panel"? I think sometimes clinicians might not know what that next step is, so they might be... just kind of avoid the conversation, almost, to avoid having to get into that part of it. So I think sometimes it's just a lack of knowledge, I guess is what it comes down to.

They also commented that specific training on the rights notification process itself was nonexistent (falling under the Skills domain of the TDF), and they reported differences in the level of formal training on the Mental Health Act among different types of health professionals (for example, registered nurses generally receive less training on the legislation compared with registered psychiatric nurses):

05-29-12 (nurse): I think when you look around, our staff makeup... is the different education backgrounds that we come from. Some are RNs [registered nurses], some are RPNs [registered psychiatric nurses], some have been around for 20 years, 30 years, some for two years. And I think the big thing is, like, there's not a lot of emphasis on the Mental Health Act. I know in my RPN program, we had a semester, we had a full course on it, but that's very few and far between. I've noticed that some of the schools, like, when you get new grads, they've never even gone over a Form 13. And that's not something that's included and part of our initial orientation either. [...] I think something like that would be more useful to get clinicians and make sure that we are providing consistent rights and reading the rights to the patients.

$\star \star \star$

07-27-10 (nurse): Pretty much all of our education as nurses, RPNs and RNs, is, like, there's, like, really no, like, Form 13 education. [...] There's no, like, going in depth into actually understanding what it means. [...] If they want a review panel, you would fill out the review panel form. We don't actually really, like, describe what a review panel is or, like, what the real process is behind it. So it's, like, a lack of education for all staff.

Although most participants felt that giving rights information was within their scope of practice (Social/Professional Role in the TDF), some questioned whether this task was appropriate for clinicians without legal training:

07-27-09 (nurse): I don't think l'd be able to speak to sort of, like, the human rights law associated with involuntary certification and ramifications of that. I don't have the legal training. Just like we wouldn't expect a lawyer to come in and do... complete a nursing pass that they've never done or had training on.

\section{At the time of admission, patients are not receptive to new information}


This theme falls under the TDF domains of Environmental Context and Resources, Beliefs about Capabilities, Optimism, and Beliefs about Consequences (see Table 1).

Participants reported that patients were often too ill to be cognitively able to understand or remember rights information when they were admitted, a factor within the Environmental Context and Resources domain:

05-29-02 (nurse): A lot of times our clients, like, their cognitive capacity to understand the Mental Health Act and how it works is quite limited, and even when we do our best to try and explain it at a level that they understand, we have clients, you know, applying for review panels thinking that that's their ticket out of hospital and that's gonna get them housing faster, so not really understanding, and it's hard to kind of, I don't know, explain it at a level that they're gonna kind of understand and makes sense to them.

\section{***}

05-24-16 (nurse): I had to do a Form 13 yesterday. You know, sometimes people are just so unwell at the point that you're doing it that it just goes over their head.

$\star \star \star$

07-27-12 (nurse): Well, obviously in mental health, there's varying levels of acuity, [...] so when a patient comes in, they're maybe withdrawing from drugs or maybe psychotic or agitated. That might not be necessarily the right time for them to be receptive to feedback, or they just can't, like, mentally process what you're talking about.

The assumption that a patient would not understand the information may discourage some clinicians from giving patients rights information. In other words, clinicians were pessimistic (TDF domain of Optimism) that they would be able to convey information in a way patients would understand, given their mental state (TDF domain of Beliefs about Abilities).

05-24-06 (nurse): Some people just assume that they won't understand the rights, and so they're not done.

Similarly, some clinicians believe that giving rights information to patients who are already angry about being detained will further upset or agitate them (TDF domain of Beliefs about Consequences).

07-17-01 (nurse): I've been working in psychiatric nursing all my career, and for me the number one barrier is the assumption that patients won't understand, we're going to upset them, you know, we'll increase their agitation, you know, because then they will want, you know, their rights to be exercised immediately, and then we don't have the resources to fulfill that right immediately.

$\star \star \star$

06-12-01 (nurse): Sometimes the patients are... when they come in, they don't want to be in, so they're quite angry. So to tell them that they're... what their rights are would be quite detrimental-just anger provoking. When we do read them the rights with that paper, we have to read it aloud to them. I find it's too long, and they either lose interest or, again, they get angry. [...] And, I mean, honestly yeah, the nurses are all, "Yeah, I don't want to do it because I don't want to provoke" whatever.

\section{The tool used to communicate rights information to patients (Form 13) is inadequate}


This theme falls under the TDF domains of Environmental Context and Resources, Beliefs about Capabilities, and Beliefs about Consequences (see Table 1).

Several participants said that a major barrier to effective communication about rights with involuntary patients was the long, overly complex language on Form 13 (an element of their Environmental Context and Resources). Not only did participants feel unable to interpret this information in a way patients could understand (TDF domain of Beliefs about Capabilities), but many of them believed that the legal nature could breed mistrust between the patient and the treatment team (TDF domain of Beliefs about Consequences):

05-29-20 (nurse): That form is really wordy. So it's really hard for me to give a Sparks Notes version of that form, so that's one thing.

\section{$\star \star \star$}

06-12-03 (occupational therapist): I feel like the Mental Health Act, it's written out for clinicians, not for patients, so we're essentially just regurgitating information that could be stigmatizing towards clients, so as soon as you say, like, "Your rights have been taken away," or whatever it may be, that's a trigger, that's gonna escalate them, they're not going to retain any of that information.

\section{$\star \star \star$}

06-12-05 (nurse): It uses legal jargon. I just had a conversation with a patient just before coming here, and seeing the legal jargon and stuff like that, he automatically assumed "If my lawyer's not here, if I don't have a lawyer present, I'm not signing anything. I don't care what you tell me it's about. I'm not."

\section{$\star \star \star$}

07-27-03 (nurse): Well I think all of the language in Form 13, it's just not really accessible to a lot of patients, especially if there's a language barrier, a literacy barrier, anything, it's totally not accessible. That's sort of my main observation of it.

\section{Many patients don't speak English}

This theme falls primarily under the TDF domain of Environmental Context and Resources (see Table 1).

Participants frequently mentioned that their patients came from many cultural and linguistic backgrounds but Form 13 is available only in English. Not having means to communicate rights information in other languages-an issue within the TDF domain of Environmental Context and Resources-was a barrier for many of the clinicians.

05-24-06 (nurse): I find, obviously, the language barrier, like, the biggest barrier for me. [...] Because, again, you have to wait, get a translator to do that, and then things just get lost in the clutter. So I think that's a big thing.

\section{$\star \star \star$}

05-29-11 (nurse): [A barrier to giving rights information is the] language barrier because, you know, here, there's a lot of different languages. This [Form 13] is only English, and then you have to translate verbally in that language. 
07-27-01 (nurse): With the population I work with at [site redacted] and geri[atric] psych[iatry], people are coming in with dementia, delirium, so they may not understand. So a lot of times I'm having family members sit in while I read it. And we have a lot of people who don't speak English. That seems to be the majority rather than the minority, so it's a real issue. You're explaining to family and they're translating it.

Clinicians said that even when interpreters were available, their focus was usually on conveying treatment information and not rights information.

05-24-00 (nurse): Like, they have interpreters when they're having their assessments with their physician, but I don't know then if that [rights information] would be something that would be highlighted to the physicians to discuss when the interpreter's around.

Beyond language, different cultural understandings of mental illness and the health care system presented barriers as well:

05-29-15 (nurse): I worked in emergency, and we saw patients who had been brought in from the airport. And this was a big issue. It was culture. It was... not just this... the simpler barriers of language and time changes and things like that, but it was it was definitely culture. It was respect. There were a lot of things... So for the emergency setting, I think those were barriers, definitely.

\section{Clinicians have many competing priorities in the admission process, which can be busy and chaotic}

This theme falls under the TDF domains of Environmental Context and Resources and Social/Professional Role (see Table 1).

Several participants described the involuntary admission process as being hectic, with many forms that have to be completed, a factor in the TDF domain of Environmental Context and Resources. The amount of information that the patient has to process about their reason for detention and their diagnosis or proposed treatment may already be overwhelming, and clinicians facing a heavy workload with many responsibilities may consider giving rights information a lower priority compared with these clinical details (TDF domain of Social/Professional Role).

05-29-03 (occupational therapist): I think often it's sort of offered as part of the admission process, and there's a lot of processes that have to go on at admission day, so I think time is limited, and that's a big barrier.

$\star \star \star$

06-12-08 (nurse): I think for me, my own experience, a barrier to providing rights advice is often a lot of the Mental Health Act information is distributed during admissions, and if an admission comes in at 2:00 in the morning, there's no way there's gonna be ample time or appropriate time to discuss it, so it kind of gets left to the wayside in hopes that the day nurse next day will carry it on, and if that's not communicated effectively, it just kind of gets pushed and pushed and pushed along until someone's like, "Oh my god-this hasn't been discussed at all."

07-17-01 (nurse): Usually it's the nurses who are dealing with the triage and the assessment are the ones to be dealing with that [rights information] most often. And so at the back of your head, you're thinking, "Oh, I have two more patients to see, I have three more..." I feel the time factor can play a role in that. 


\section{Clinicians face pressure from other staff not to give rights information in an understandable way}

This theme falls under the TDF domains of Social Influences and Environmental Context and Resources (see Table 1).

Some clinicians acknowledged a conflict of interest that may prompt them to give patients rights information in a way that doesn't necessarily encourage understanding. When patients choose to exercise their rights, such as when they apply for a review panel hearing, they initiate legal processes that demand staff time and resources (TDF domain of Environmental Context and Resources). As a result, some clinicians face social pressure from their colleagues (TDF domain of Social Influences) to downplay rights information, and there appears to be an organizational culture to see review panel hearings as a burden rather than as a therapeutic opportunity to further a patient's sense of procedural justice.

07-27-14 (social worker): I think that the staff [...] have a tendency to do things that are required of them in this regard but not necessarily to go above and beyond that, to actually help someone understand, as opposed to just going through the motions of showing them a list of their rights and asking them if they have any questions. But again, if they're not in a state of mind to process a lot of information in that exact moment, then there might not be another opportunity that presents itself for patients to really ask those questions and really understand what their rights are. And I think there's a certain, like, intention behind that as well, to be honest. Review panels take a lot of work and time, and sometimes they're perceived as a barrier to, again, from a paternalistic point of view, achieving and executing a care plan or a treatment plan that the care team specifically-often the psychiatrist-has in mind, right? So I think there's that side of the equation as well.

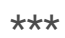

06-12-12 (nurse): The other thing we see is, when you're offering something like "You have the right to a review panel." Physicians don't want review panels. They take up a lot of time. They take up a lot of work. So they're going to... you know, the information that the patient's getting, maybe they're glazing over that part about review panel because they don't want to have to spend the X amount, you know. So to me that is a direct conflict of interest.

\section{The clinical workflow doesn't facilitate follow-up and accountability}

This theme falls under the TDF domains of Environmental Context and Resources, Social Influences, and Social/Professional Role (see Table 1).

The Mental Health Act requires only that patients be notified of their rights if they are transferred between facilities and not when they are transferred between units at the same facility. When a patient arrives at a unit, clinicians assume that if a Form 13 appears in their file, they have been told about their rights, but whether the patient has in fact been explicitly told and whether they have understood is not always clearly documented.

07-17-02 (nurse): We send them up [to the inpatient unit] with the forms that have been signed, so if the Form 13 has been signed, then I think that that would communicate to the inpatient unit that this has been communicated to the person. And if it's not signed, then I think it would communicate to the inpatient unit that they may need to provide that information. But there's no direct, formal communication to say, "Hey, we informed them of their rights" or anything like that. 
Whether patients have received and understood rights information is also poorly communicated and documented over shift changes:

07-27-06 (nurse): I think what participant number two [07-27-02, a nurse] said in terms of, like, the ability to communicate fluidly with your colleagues around the status of the patient and what their rights [...] like, what the conversation has been so far, we don't have great systems to document that well. [...] It's just fragmented, and there's not a really clear system in place for clinicians to understand what the conversation has been, and especially when there's shift change at minimum, you know, twice a day [...] so systems for clinicians, and we only have... We have the Form 13-that's the only resource we have to go off of.

When patients refuse to hear about their rights when they arrive, or if they appear not to understand, the Mental Health Act says that they must be offered rights information again later in their stay. Clinicians acknowledge, however, that they have no standard systems to track which patients need their rights repeated and when. This lack of tracking and accountability systems reflect a problem within the TDF domain of Environmental Context and Resources as well as a social or organizational culture that has not prioritized creating such systems (TDF domain of Social Influences).

05-24-16 (nurse): People are coming in and maybe they're not in a state of mind where they're able to hear and understand the information that you're providing, and then, um, and then it's sort of losing track of that, I think, and not revisiting it at a time when they're more able to hear that information and understand that information.

\section{$\star \star \star$}

06-12-05 (nurse): Sometimes passing along to our cohorts about what we've been able to accomplish for that kind of discussion or not isn't really written down, so somebody's attempted but then that person goes off for the next three days, and that nurse isn't back to check in for the next little bit, so it gets lost in translation there. Yeah. People will see you've attempted and assumed that an attempt means a full conversation when it was just an attempt.

$\star \star \star$

05-29-16 (nurse): Sometimes if someone isn't wanting to [hear rights information], like, you'd write, you know, "Patient declined to hear," or whatever, but then it doesn't get followed up with or, you know, it kind of gets put away because that check box is now checked.

Because any number of clinicians may give patients rights information, participants said that uncertainty about whose responsibility it was (TDF domain of Social/Professional Role) led to further confusion.

06-12-08 (nurse): Back in the day when we did have primary nursing in more acute settings, I feel like information was way more consistent, but now that that's not a scenario that we have anymore, I do think that kind of hinders having consistent advice being provided.

07-17-05 (social worker): I think clinicians assume the doctor has talked to the patient about being certified. Sometimes with patients who don't know they're certified, we've gone and done all these forms, and there's a miscommunication of who's actually told the patient what's going on.

\section{The organization doesn't give staff enough resources and support}

Page $11 / 30$ 
This theme falls under the TDF domains of Environmental Context and Resources and Social/Professional Role (see Table 1).

One clinician recalled her experience working in another province where the resources devoted to record keeping allowed for more accountability. In BC, where historically resources had not been allocated to auditing patient files, clinicians may not complete the forms, including Form 13, with as much care.

06-12-05 (nurse): I started practising in Alberta first before coming out here, and I was used to a system where, like, health records and so on and so forth were actually in charge of receiving the forms and ensuring that the dates and everything made sense, whereas here it seems quite strange to me that we complete them, they go in the back of the chart, and unless somebody asks to go to review panel, it's not being reviewed or seen, so things can have lapsed or not have made sense. Sometimes you go quite far back and realize, OK, you know, actually, the forms were messed up six months ago, and you're not actually certified. All these different things, so, yeah, it's just kind of interesting that, yeah, they do it completely different than here.

Some clinicians cited a general lack of organizational support and staff needed to truly answer patients' questions about their rights and their concerns about their involuntary hospitalization (TDF domain of Environmental Context and Resources):

06-12-03 (occupational therapist): At times we could not have enough staff or just things are busy, so getting the accurate explanation of the Mental Health Act might be challenging.

06-12-02 (social worker): If we were concerned about it, we could put on more staff. There could be more staff. So on any given day, there really is not adequate staff. And management could make the choice to change that, or not. So given at the start of every day, there's not adequate staff, then people are trying to get all those things done, and of course my colleagues have discussed some of the difficulties with that. [...] I get a lot of concerns [from patients] about, say, how long does somebody have to remain certified, and then people will naturally tend to go off on that tangent. So very time consuming, because I don't want to escalate the patient and make things worse, so I might end up being a half an hour going over a form with them.

Finally, some participants suggested that the problem of clinicians failing to give involuntary patients consistent and complete rights information reflected their part (TDF domain of Social/Professional Role) within a paternalistic system that devalued patients' rights and prioritized expedience over the patient experience, from police apprehension through to discharge.

07-27-13 (social worker): My impression is that it's not necessarily prioritized as, like, a primary responsibility. I think that there's not the, like, culture or the systemic support to help maybe prioritize rights advice in hospital... maybe the support that we need to be able to do that more effectively. I think sometimes there's maybe a bit of a, like, some of it's, like, about stigma. Some of it's about attitudes, maybe, that clinicians might have around, like, their patients or perceptions around, like, what asking for information about your rights and, like, maybe some of the judgments that go on around that. I think we have some paternalistic attitudes in psychiatry, and so I think that influences maybe some of... I think that is a barrier. 
07-17-07 (nurse): I don't think the system is actually providing any support, specific support towards that [giving patients rights information. [...] My experience was the other day working with a person that there are other systems involved-like, I mean, police is involved, I'm involved, ambulance is involved, and I'm trying to provide... like, I'm using least intrusive... and explaining everything, but the officer is standing there. She must be having a crunch by the time she has stepped forward and said, "That's it, I'm handcuffing the patient, we're going." Which I totally understand. I'm not saying it from the point of criticism. But I'm saying that sometimes it's a multifactorial situation, and it's not that easy that we would, say, I would walk towards my patient and I say, there are so many other things in the background that it does play its own role. That it should be addressed as a whole. But definitely, I mean, my experience, it's a system issue.

\section{Facilitators}

Although most of the participants' comments related to barriers to giving patients rights information, some did mention factors that supported this behaviour.

\section{A team approach allows clinicians to learn from one another about the Mental Health Act and about the rights-notification process}

This theme falls under the TDF domains of Social/Professional Role and Social Influences (see Table 1).

Some clinicians reported learning from more experienced colleagues about the Mental Health Act (thus help defining their Social/Professional Role, per the TDF), which helped increase their confidence in giving rights information to involuntary patients.

05-24-16 (nurse): A facilitator for that [being confident in giving rights information] is every work environment that I've been in, people are super supportive in helping you with those things, so having other nurses there to help is good.

$\star \star \star$

06-12-08 (nurse): I think just having experienced colleagues, you know, for situations where questions come up and you're not sure how to answer them or for newer staff who are not sure when to approach a patient so that they'd be open and able to understand information and getting advice from colleagues about that could be something that supports that information getting distributed.

Several participants said that different members of the treatment team can remind one another of the responsibility of giving rights information to ensure that it is done (TDF domain of Social Influences).

05-24-12 (nurse): I think we... in hospital, it gets overlooked sometimes because we're in such a rush, especially when it's, like, admission, [...] but I think it's really important that we just kind of, like, you know, like, clinician to clinician to remind ourselves, like, what we're really doing for these clients and that they really... they need to know their rights. And just kind of thinking about putting ourselves in their shoes. If we were admitted, of course, we'd want to know. 
06-12-05 (nurse): Usually I find that our physicians are trying to complete this process together, like, so acknowledging and talking about their rights as a part of, already, when certification's completed, [...] so it's not just myself alone with the patients. The doctor's also involved. So I find that helpful.

$\star \star \star$

07-17-05 (nurse): And I think maybe asking the doctor, "Have you explained this or not?"

07-17-02 (nurse): "Would you like me to explain this?"

07-17-05 (nurse): Yeah, exactly. They're time-pinched, too.

\section{Having one person take responsibility for rights information clarifies clinicians' roles and increases accountability}

This theme falls under the TDF domains of Social/Professional Role and Intentions (see Table 1).

A primary nursing model, where each patient is assigned a nurse who is primarily responsible for their care, clarifies that giving rights information is that nurse's responsibility (that is, their Social/Professional Role in the TDF). A nurse who serves as coordinator in a unit may also regularly review patient files to ensure that each patient has been given their rights information when they are receptive to it. This clarity in role reinforces the clinician's intent (TDF domain of Intentions) to give rights information.

05-29-17 (nurse): Well, I'm coordinator on the fourth floor, and so I do an audit, three to four days, or maybe a week, after the person has been admitted, and I go and I look and see a lot of times the client refused to sign. So ideally they're a little bit more settled, so sometimes then I take the form and I go back and sort of continue that work.

$\star \star \star$

06-12-10 (research assistant): I work primarily upstairs, um, where each patient has a primary nurse that they're working with, so mainly having it be, like, the job of one person instead of hoping that somebody in the group has done something about it. The primary nurse of the patient would check in with them and make sure they understand that.

\section{***}

06-12-12 (nurse): We do do primary nursing upstairs, so generally the primary nurse, it's their responsibility to have that conversation, the rights advice conversation with the client, because they have the most rapport developed already.

\section{Accreditation processes remind clinicians of the importance of giving rights information to involuntary patients}

This theme falls under the TDF domains of Social/Professional Role, Reinforcement, Goals, Behavioural Regulation, and Environmental Context and Resources (see Table 1).

One clinician stated that when their facility underwent an accreditation process, it reinforced the need for consistently completing the forms as required by the Mental Health Act. An external organization auditing and evaluating the facility's practices (TDF domains of Environmental Context and Resources and Behavioural 
Regulation) based on a set of standards (TDF domain of Goals) reminded clinicians of the consequences of not fulfilling their legal obligations to give patients rights information (TDF domain of Reinforcement) and reminded them of their responsibility (TDF domain of Social/Professional Role).

07-27-10 (nurse): Something like being accredited through Accreditation Canada, as one of the other participants was saying, really pushed us to understand, like, “Oh, we have this gap in our care and we hadn't recognized it before" [...] Like that Form 13s need to be happening consistently, every single time that someone is either certified or if they have, like, that change in consciousness or cognitive ability, where those major changes are occurring, that we should be also doing it at those points.

\section{Checklists remind clinicians of their rights-notification responsibilities}

This theme falls under the TDF domains of Social/Professional Role and Environmental Context and Resources (see Table 1).

At one of the sites where we conducted focus groups, clinicians said that they had developed a series of checklists (thus introducing a tool to their environment-TDF domain Environmental Context and Resources) to delineate clinicians' responsibilities within the involuntary admission process (that is, defining their Social/Professional Role) and sample forms to increase the likelihood that the Mental Health Act forms, including Form 13, would be completed as the legislation requires.

06-12-12 (nurse): We created a Mental Health Act checklist. So basically the checklist was to clarify who's responsible to do what forms and when. The checklist is accompanied with an SOP, a standard operating procedure, which staff can use to help guide them. It's just a little bit more detail. But the checklist breaks down what forms are needed, and we ask for the date, and then who was the person that signed that. [...] It's worked really well for our unit. It's caught a lot of errors, generally from the community, where there's a lot of errors coming in for certification, and then it also keeps track of who's doing what when and whose responsibility. Because a lot of times with paperwork, it's, like, "Oh, well, I don't do that-that's not my job." We have it explicitly kind of broken down -whose job is it to do what.

At other sites, clinicians suggested using checklists to document whether patients had received and understood their rights information and to communicate this information to their colleagues across shift changes.

07-27-02 (nurse): We do have kind of this mental health form checklist that prints out with the chart packs. I don't know if we could do some kind of, um, tweaking to it where, under the Form 13, like, if they refuse to sign, like, someone could make a note, like, "Refused to sign" or "Did not appear to understand-follow up." And it could be something that is that communication tool.

$\star \star \star$

05-24-16 (nurse): In your Kardex [medical information system for nursing staff to communicate] and in your charting and stuff you should be sharing... or documenting whether or not information has been shared and what information needs to be revisited, but then it's the carrying over of that information I think... It's good and fine to put it in a Kardex one day, but then if it hasn't been done again, is it going to be in the Kardex the next day? And so... and maybe if there was some sort of a formal way of documenting that.

One participant said that a poster may also remind clinicians to give rights information to involuntary patients.

Page $15 / 30$ 
07-17-07 (nurse): I think partially what can help me is just having a poster as a reminder. [...] It would be this as a reminder in the unit, you know, having that every time I pass by it, even if I have a glance at it, I would just, "Oh, OK, I should remember." I should remember, you know, just to explain the rights of the patient to the patient when they are involuntary.

\section{Hypothetical facilitators}

During the discussion participants also suggested services or programs that did not exist but could facilitate their task of giving rights information to involuntary patients.

\section{A legal or advocacy service that clinicians could contact with questions about the Mental Health Act would allow clinicians to better help patients exercise their rights}

This theme falls under the TDF domains of Knowledge, Social/Professional Role, and Environmental Context and Resources (see Table 1).

Several participants said that they would appreciate a service staffed by lawyers or legal advocates well versed in the Mental Health Act (thus adding to their Environmental Context and Resources) that they could freely consult to answer their own or patients' questions relating to the legislation (TDF domain of Knowledge). Some participants understood that as clinicians, they could not be expected to be experts on the law (TDF domain of Social/Professional Role) but they expressed a reluctance to contact legal professionals directly, owing to cost.

07-17-01 (nurse): When Riverview [psychiatric hospital] was fully functioning [...] there was a direct call to Riverview review panel there, and they have that patient rights department, where you just call in, and patients... they can speak directly to the patient as well, so that system was there, where you have direct contact to the review panel or patient rights advocacy at Riverview Hospital.

$\star \star \star$

07-17-02 (nurse): Yeah. I wonder if a service like that, that would have to almost act like a consultation service where things get a little bit more in-depth, where it is beyond our ability to explain, you know, where it becomes a little bit more legal, a service like that would probably be helpful, where we can almost call in and receive for ourselves or for our clients some advice around, "OK here's a really good question that I don't know the answer to," and maybe somebody who has some legal background might be able to answer it for us. That would be, I think, a helpful service.

$\star \star \star$

07-27-10 (nurse): the thing that I would like to see, like someone like CLAS [Community Legal Assistance Society] or another organization is to basically have, that almost like an open line of communication, so that you have, like, access to someone that you're not, um, feeling like you're taking up their time for free asking questions about, you know, like, "My patient is asking me this, how do I figure this out?" [...] Like, an open email that gets answered every day or something like that, so that you're not feeling like you're taking up a lawyer's time, because it's like... that's, like, I think one of the sort of, like, rumours or ideas that lawyers, like, they're so expensive, it's like, why would you call a lawyer-maybe, like, you'll get charged. 


\section{Regular, open information sessions for patients would give them opportunities to learn about their rights when they are ready to receive the information}

This theme falls under the TDF domain of Environmental Context and Resources (see Table 1).

Some participants suggesting reviving old or revising existing group programs (thus adding to the Environmental Context and Resources) to offer patients other means of learning about their rights beyond the rights notification required during the admission process. These programs would give clinicians an opportunity to convey rights information when patients may be more receptive to it.

05-29-10 (recreational therapist): I used to work at Riverview way back 20 years ago, and MPA [an advocacy and empowerment group for people with mental illness, known at the time as the "Mental Patients' Association" and now known simply as the MPA Society] did a lot of the advocacy, and we... they had a coffee program, and clients could come when they were ready to come and seek that... advice or that support. It'd be kinda cool to have something like that monthly here or something, where if somebody wants to know more information, they could come, so it's not, like... Like, I think when you take it to the unit, then it's kind of being forced on them, but it's almost better when they are coming themselves to find out the information. It's more like you have this opportunity, you can go down and you can find it, and I think it's empowering the clients a little bit more when you have something that's more like on a drop-in basis or something like that.

$\star \star \star$

07-27-14 (social worker): We have a group program, and we could easily facilitate someone coming in and presenting on these issues, yeah, and helping clients have the space and time to actually contemplate and think about and ask questions. As opposed to the sometimes rushed clinical process after the context of a psychiatric appointment that's, like, very short.

\section{Discussion}

The target behaviour in this investigation is for clinicians to consistently give each involuntary patient complete rights information-upon admission and, if necessary, again later in the patient's hospital stay, if at admission they refuse to hear their rights or don't understand.

Thematic analysis of the focus group contributions identified these barriers to the target behaviour:

- Clinicians receive inadequate training on the Mental Health Act generally and rights notification specifically.

- At the time of admission, patients are not receptive to new information.

- The tool used to communicate rights information to patients (Form 13) is inadequate.

- Many patients don't speak English.

- Clinicians have many competing priorities in the admission process, which can be busy and chaotic.

- Clinicians face pressure from other staff not to give rights information in an understandable way.

- The clinical workflow doesn't facilitate follow-up and accountability.

- The organization doesn't give staff enough resources and support.

Themes also suggested these facilitators: 
- A team approach allows clinicians to learn from one another about the Mental Health Act and about the rightsnotification process.

- Having one person take responsibility for rights information clarifies clinicians' roles and increases accountability.

- Accreditation processes remind clinicians of the importance of giving rights information to involuntary patients.

- Checklists remind clinicians of their rights-notification responsibilities.

In response to the barriers raised in the discussion, participants proposed possible solutions that we classified as hypothetical facilitators:

- A legal or advocacy service that clinicians could contact with questions about the Mental Health Act would allow clinicians to better help patients exercise their rights.

- Regular, open information sessions for patients would give them opportunities to learn about their rights when they are ready to receive the information.

This section synthesizes proposed interventions that may help support the target behaviour from three sources:

1. the TDF and associated taxonomy of behaviour change techniques [18, 19], which offer a theory-informed method to identify interventions based on the domains coded to the themes,

2. participants' own suggestions, articulated during the focus group discussions, and

3. the recommendations from a report released by the BC Office of the Ombudsperson, which detailed the findings of its investigation into health authorities' failure to uphold the rights of involuntary patients as required by the Mental Health Act [8].

The behaviour change techniques associated with each TDF domain assigned to each theme and subtheme, as well as the proposed interventions that employ those techniques, are summarized in the rightmost columns of Table 1.

\section{Training for clinicians about the Mental Health Act and rights notification}

One of the recommendations of the BC Office of the Ombudsperson was for

the Ministry of Health, together with the health authorities, [to] develop and implement a mandatory training plan for all directors, physicians and other staff exercising authority under the involuntary admissions provisions of the Mental Health Act, and ensure that those individuals complete the revised training [...] and all new staff complete the training within one month of hire. (p. 98)

Clinicians who participated in the focus groups also suggested that more training for new hires and regular training to refresh staff understanding of the Mental Health Act and on the rights-notification process would help increase their knowledge of the legislation and confidence in answering patients' questions. Frequent, interactive training that is tailored to the clinician group and is supported by management has been found to be more effective than generic training that is delivered only once [20,21, 22]. Although the BC Office of the Ombudsperson recommended that the Ministry of Health work with health authorities to revise their training based on provincewide standards, 
individual hospitals may wish to consider tailoring training programs to their sites, based on their staff composition and clinical workflows, perhaps by co-creating these programs with clinicians.

Because participants reported a lack of knowledge about the law as well as a lack of confidence in giving rights information, regularly offered training that (a) conveyed information about the Mental Health Act, clinicians' responsibilities to give rights information under the law, as well as the possible therapeutic benefits of giving rights information and (b) gave clinicians the opportunity to practise the target behaviour would be an appropriate intervention to address the domains-including Knowledge, Skills, Social/Professional Role, and Beliefs about Capabilities-pertaining to these themes. Mandatory training may also begin to foster an organizational culture that puts more emphasis on rights information, affecting the domain of Social Influences. The practice, in particular, where clinicians could mentally rehearse successfully performing the target behaviour, may increase their optimism for a positive outcome in the rights-information interaction and decrease their anticipated regret (affecting TDF domains of Optimism and Beliefs about Consequences).

\section{An open legal resource for clinicians and patients}

To address the conflict of interest that may discourage clinicians from providing complete rights information, the $\mathrm{BC}$ Office of the Ombudsperson recommended that the provincial government fund a body independent of the health authorities to provide involuntary patients with rights advice and advocacy.

Focus group participants' attitudes toward this proposed service were mixed [11], with some enthusiastically supporting the idea but others concerned that adding more people to the clinical workflow would increase confusion. However, many said they would appreciate a legal resource they could consult if they encountered rights questions they couldn't answer.

Some suggested a legal hotline, a phone number, or email address that either clinicians or patients could access for Mental Health Act legal advice or guidance on interpreting the law. Although each health authority has a risk management office that can give legal guidance for particular situations, clinicians expressed an uncertainty about using them or outside counsel owing to scope and cost.

Adding a legal resource would restructure the social environment to offer more knowledge and social support to clinicians and may shift some of the rights-advice responsibilities away from clinicians and lightening their workload. In terms of the TDF, an easily accessible legal resource would add to the Environmental Context and Resources and clarify the Social/Professional Role of clinicians.

\section{Regular group sessions about rights for patients}

One of the strategies clinicians proposed to address the barriers resulting from patients who are not receptive to rights information at the time of admission is to offer group sessions that patients could attend at their leisure. Clinicians believed these sessions would give patients an opportunity to learn more about their rights on their terms, when they were ready to hear the information, and a longer session could give patients the opportunity to ask questions, which the rushed admissions process may not accommodate well. Clinicians also suggested that patients would be more receptive to the rights information if they sought it out voluntarily at these sessions. If these sessions were facilitated by staff who were not on the patients' treatment team, they would also remove the conflict of interest that may prompt clinicians to avoid giving complete rights information. 
In the language of the TDF, this proposed group session could help restructure the social environment (a technique associated with the Environmental Context and Resources domain) to give both clinicians and patients a less confrontational venue to convey rights information.

The report from the Office of the Ombudsperson did not explicitly propose this intervention.

\section{An Improved rights-communication tool offered in multiple languages}

To address the barrier of an inadequate communication tool, Form 13 could be replaced or supplemented with a tool that is user tested with involuntary patients to ensure that the level of language and tone are appropriate for them. This strategy corresponds to the behaviour change technique of "adding objects to the environment" (TDF domain of Environmental Context and Resources) that would promote the target behaviour.

An effort to develop a patient-centred suite of rights-communication tools has been undertaken [10]. Several elements of this suite have been translated to eight languages other than English, to accommodate some of the linguistic diversity of the patient population. The effectiveness of this suite of tools at increasing patients' understanding of their rights has yet to be evaluated in the clinical setting.

Interpreters will still be needed, especially for patients who speak or sign languages not served by the translations or who are not able to read. Focus group participants also suggested that the rights information be audio recorded in different languages and made available to clinicians to play for patients as needed.

This intervention was not explicitly recommended by the BC Office of the Ombudsperson.

\section{Checklists, reminders, and accountability and feedback systems}

The BC Office of the Ombudsperson recommended that "the Ministry of Health and the Ministry of Mental Health and Addictions work together with the health authorities to establish clear and consistent provincial standards aimed at achieving 100 percent compliance with the involuntary admissions procedures under the Mental Health Act through the timely and appropriate completion of all required forms" [8, p. 97], including Form 13, and that these standards be codified in a regulation under the Health Authorities Act and evaluated for effectiveness in increasing compliance rates. These measures may function in the same way as the accreditation process that some participants found helpful in reminding clinicians of their responsibilities (TDF domain of Social/Professional Role).

Focus group participants proposed using checklists and posters as reminders of their duties, and these additions to the work environment (TDF domain of Environmental Context and Resources) may help clinicians set goals (TDF domain of Goals) to implement the standards. Checklists have been found to increase clinician compliance with regulations and guidelines [23], and the best results arise when clinicians who will use the checklists help develop them and suggest ways they can be integrated into their workflow [24].

The BC Office of the Ombudsperson further recommended that the health authorities implement a system to store Mental Health Act forms so that they can be easily accessed and tracked. These records would be subject to regular audits to ensure compliance with the Mental Health Act. This recommendation adds an element of monitoring and feedback to support the target behaviour (TDF domain of Reinforcement), similar to the role that 
accreditation played at one of the sites where focus groups were held. This type of audit and feedback has proven to be effective at changing behaviour when it is done repeatedly, is given by a supervisor or colleague, and has clear targets and an action plan [25]. This behaviour change technique addresses the Behavioural Regulation domain identified within this theme.

In developing the provincial standards, the stakeholders could aim to incorporate other facilitators that the participants identified, including assigning oversight responsibility for ensuring rights information is given to a single person in each unit, which participants suggested would clarify professional roles and increase accountability.

\section{Limitations}

The study was limited in the following ways: The focus groups involved clinicians at a small number of hospitals within a single metropolitan area. Clinicians in other parts of the province, particularly in rural and remote locations, may have quite different perceptions of barriers and facilitators to giving consistent and complete rights information to involuntary patients.

The focus groups probed barriers and facilitators as perceived and reported by the participants, and their perceptions may not include unconscious barriers. Further data collection from other stakeholders in the rightsnotification process and an accompanying realist analysis may help identify the mechanisms driving clinicians' behaviour [26].

A few factors may have biased the data collected. First, the focus groups were voluntary, and the topic was well advertised in advance. Clinicians who are strong advocates for stronger involuntary patients' rights may have selfselected to participate, whereas clinicians who believe in restricting patients' rights may have avoided the sessions. Second, although all clinicians who give rights information were invited to participate, the study was not able to engage any physicians, the group empowered under the Mental Health Act to authorize patients' detention. Dedicated efforts to reach this key group of stakeholders may yield further insights on possible interventions.

Further, although the focus group data are anonymized, participants engaged in a discussion with their coworkers at the focus groups, and unseen power dynamics may have prevented participants from expressing themselves frankly. Triangulating the data with one-on-one interviews where participants are assured confidentiality may mitigate the effects of this possibility.

\section{Conclusions}

Psychiatric clinicians participated in focus groups about their perceived barriers and facilitators to performing the target behaviour of giving involuntary patients consistent and complete rights information. We used thematic analysis on the transcripts from these focus groups to generate a list of barriers, facilitators, and hypothetical facilitators-solutions to overcoming some barriers that participants proposed but did not exist at the time of the focus groups.

We mapped the subthemes within each theme to domains within the Theoretical Domains Framework, which we then used to identify corresponding behaviour change techniques to inform interventions likely to support the target 
behaviour. These proposed interventions are as follows:

- training for clinicians about the Mental Health Act and rights notification,

- an open legal resource for clinicians and patients,

- regular group sessions about rights for patients,

- an improved rights-communication tool offered in multiple languages, and

- checklists, reminders, and accountability and feedback systems.

Some of these interventions correspond with, or may be integrated with, the recommendations issued by the $\mathrm{BC}$ Office of the Ombudsperson. Other interventions were not explicitly addressed by the BC Office of the Ombudsperson but may still play a role in supporting the target behaviour. The results of this study demonstrate the value of consulting clinicians when developing an implementation plan that directly affects their work.

We recommend that the health authorities within British Columbia incorporate as many of these interventions as possible as they implement the BC Office of the Ombudsperson's recommendations, as means of safeguarding the rights of involuntary patients by increasing the likelihood that clinicians fulfill their legal and clinical obligations to convey rights information according to the Mental Health Act.

\section{Declarations}

\section{Declarations}

The authors declare that they have no competing interests.

\section{Acknowledgements}

Thanks are due to focus group research assistants Emily Carpenter, Alyssa Haim, Alicia Lee, Hannah Rosen, and Jennifer Tong. Thanks also to Vanessa Bland, Amy Byrne, Philip Charlebois, and Angela Russolillo for facilitating site access and advertising the sessions to clinicians.

\section{References}

1. Wyton M. Forced mental health treatment spikes in BC. The Tyee. 2021 Nov 23. Available from https://thetyee.ca/News/2021/11/23/BC-Forced-Mental-Health-Treatment-Spikes/.

2. Mental Health Act [RSBC 1996] Chapter 288. Available from http://www.bclaws.ca/civix/document/id/complete/statreg/233_99. Accessed 2018-01-31.

3. Mental Health Regulation (233/99). Available from http://www.bclaws.ca/civix/document/id/loo95/loo95/233_99. Accessed 2018-01-31.

4. Johnston L. Operating in Darkness: BC’s Mental Health Act Detention System. Vancouver, BC: Community Legal Assistance Society; 2017. Available from https://d3n8a8pro7vhmx.cloudfront.net/clastest/pages/1794/attachment s/original/1527278723/CLAS_Operating_in_Darkness_November_2017.pdf?1527278723. Accessed 2017-1130. 
5. Kreyenbuhl J, Nossel IR, and Dixon LB. Disengagement from mental health treatment among individuals with schizophrenia and strategies for facilitating connections to care: A review of the literature. Schizophr bull. 2009 Jul 1;35(4):696-703

6. Dixon LB, Holoshitz Y, and Nossel I. Treatment engagement of individuals experiencing mental illness: Review and update. World psychiatry. 2016 Feb;15(1):13-20. https://doi.org/10.1002/wps.20306

7. RA Malatest and Associates. Patient Experiences with Short-Stay Mental Health and Substance Use Services in British Columbia. Victoria, BC: RA Malatest and Associates; 2011. Available from

https://www.health.gov.bc.ca/library/publications/year/2011/BCMHSU-DescriptiveReport-2011.pdf. Accessed 2016-02-02.

8. BC Office of the Ombudsperson. Committed to Change: Protecting the Rights of Involuntary Patients under the Mental Health Act. Victoria, BC: BC Office of the Ombudsperson; 2019. Available from

https://bcombudsperson.ca/sites/default/files/OMB-Committed-toChange-FINAL-web.pdf. Accessed 2019-0310.

9. Graham ID, Logan J, Harrison MB, Straus SE, Tetroe J, Caswell W, Robinson N. Lost in knowledge translation: time for a map? Journal of continuing education in the health professions. 2006 Dec;26(1):13-24.

10. Cheung IW. Improving Patients' Understanding of Their Rights under British Columbia's Mental Health Act (Doctoral dissertation, Simon Fraser University, Faculty of Health Sciences). 2019. Available from https://summit.sfu.ca/item/19351

11. Cheung IW, Bland VR, Castro-Noriega E, Silva DS, Miller KJ, Michalak EE, Goldsmith CH. Pilot of a Training Format for Clinicians' Continuing Professional Development: Open House With Rotating Short Segments. The Journal of continuing education in the health professions. 2021 Jun 8.

12. Braun V, Clarke V. Using thematic analysis in psychology. Qualitative research in psychology. 2006 Jan 1;3(2):77-101.

13. Cane J, O'Connor D, Michie S. Validation of the theoretical domains framework for use in behaviour change and implementation research. Implementation science. 2012 Dec 1;7(1):37.

14. Atkins L, Francis J, Islam R, O’Connor D, Patey A, Ivers N, Foy R, Duncan EM, Colquhoun H, Grimshaw JM, Lawton R. A guide to using the Theoretical Domains Framework of behaviour change to investigate implementation problems. Implementation science. 2017 Dec 1;12(1):77.

15. Michie, S, Johnston, M, Francis, JJ, Hardeman, W, Eccles, MP (2018) From theory to intervention: mapping theoretically derived behavioural determinants to behaviour change techniques. Appl Psychol: Int Rev. 2008, 57: 660-680.

16. NVivo [Qualitative data analysis software]. Melbourne, Australia: QSR International Pty Ltd; 2018. Available from https://www.qsinternational.com/nvivo/nvivo-products.

17. Cheung IW, Silva DS, Miller KJ, Michalak EE, Goldsmith $\mathrm{CH}$. A qualitative study of clinicians' perspectives on independent rights advice for involuntary psychiatric patients in British Columbia, Canada. PLoS ONE. 2021 16(3): e0247268. https://doi.org/10.1371/journal.pone.0247268

18. Cane J, Richardson M, Johnston M, Ladha R, Michie S. From lists of behaviour change techniques (BCT s) to structured hierarchies: comparison of two methods of developing a hierarchy of BCT $\mathrm{s}$. British Journal of Health Psychology. 2015 Feb;20(1):130-50.

19. Michie S, Richardson M, Johnston M, Abraham C, Francis J, Hardeman W, Eccles MP, Cane J, Wood CE. The behavior change technique taxonomy $(\mathrm{v} 1)$ of 93 hierarchically clustered techniques: building an international 
consensus for the reporting of behavior change interventions. Annals of Behavioral Medicine. 2013 Mar 20;46(1):81-95.

20. Grimshaw JM, Shirran L, Thomas R, et al. Changing provider behavior: An overview of systematic reviews of interventions. Med Care Res Rev. 2001;39(8, Suppl 2):I12-45.

21. Young T, Rohwer A, Volmink J, Clarke M. What are the effects of teaching evidence-based health care (EBHC)? Overview of systematic reviews. PLoS One. 2014;9(1):1-13. doi:10.1371/journal.pone.0086706.

22. Albrecht L, Archibald M, Snelgrove-Clarke E, Scott SD. Systematic review of knowledge translation strategies to promote research uptake in child health settings. J Pediatr Nurs. 2016;31(3):235-254.

doi:10.1016/j.pedn.2015.12.002.

23. Thomassen $\emptyset$, Storesund A, Søfteland E, Bratteb $\emptyset$ G. The effects of safety checklists in medicine: a systematic review. Acta Anaesthesiologica Scandinavica. 2014 Jan;58(1):5-18.

24. Gillespie BM, Marshall A. Implementation of safety checklists in surgery: a realist synthesis of evidence. Implementation science. 2015 Dec 1;10(1):137.

25. Ivers N, Jamtvedt G, Flottorp S, Young JM, Odgaard-Jensen J, French SD, O’Brien MA, Johansen M, Grimshaw J, Oxman AD. Audit and feedback: effects on professional practice and healthcare outcomes. Cochrane database of systematic reviews. 2012(6).

26. Wong G, Greenhalgh T, Westhorp G, Pawson R. Realist methods in medical education research: what are they and what can they contribute?. Medical education. 2012 Jan;46(1):89-96.

\section{Table 1}

Table 1: Clinicians' perceived barriers and facilitators to giving involuntary patients rights information, coded to domains in the Theoretical Domains Framework [13], which are then mapped to behaviour change technique (BCT) groupings [18] in the BCT Taxonomy v1 [19]. 


\section{BARRIERS}

\begin{tabular}{|c|c|c|c|c|}
\hline Barrier (theme) & Subtheme & Domain & $\begin{array}{l}\text { Behaviour } \\
\text { change } \\
\text { technique } \\
\text { grouping }\end{array}$ & $\begin{array}{l}\text { Behaviour change } \\
\text { techniques } \\
\text { (BCTs) }\end{array}$ \\
\hline \multirow{4}{*}{$\begin{array}{l}\text { Clinicians } \\
\text { receive } \\
\text { inadequate } \\
\text { training on the } \\
\text { Mental Health } \\
\text { Act generally } \\
\text { and rights } \\
\text { notification } \\
\text { specifically. }\end{array}$} & $\begin{array}{l}\text { Clinicians don't } \\
\text { know how to } \\
\text { help patients } \\
\text { exercise their } \\
\text { rights. }\end{array}$ & Knowledge & $\begin{array}{l}\text { Shaping } \\
\text { knowledge }\end{array}$ & $\begin{array}{l}\text { Instruction on } \\
\text { how to perform } \\
\text { the behaviour; } \\
\text { Information about } \\
\text { antecedents }\end{array}$ \\
\hline & $\begin{array}{l}\text { Clinicians have } \\
\text { not been } \\
\text { trained on the } \\
\text { specific task of } \\
\text { giving rights } \\
\text { information. }\end{array}$ & Skills & $\begin{array}{l}\text { Repetition and } \\
\text { substitution }\end{array}$ & $\begin{array}{l}\text { Behavioural } \\
\text { practice/rehearsal }\end{array}$ \\
\hline & $\begin{array}{l}\text { Some } \\
\text { clinicians did } \\
\text { not feel that } \\
\text { giving legal } \\
\text { information } \\
\text { was within } \\
\text { their scope of } \\
\text { practice. }\end{array}$ & $\begin{array}{l}\text { Social/ } \\
\text { Professional } \\
\text { Role }\end{array}$ & No BCTs & \\
\hline & $\begin{array}{l}\text { Clinicians lack } \\
\text { confidence in } \\
\text { their ability to } \\
\text { give patients } \\
\text { rights } \\
\text { information. }\end{array}$ & $\begin{array}{l}\text { Beliefs about } \\
\text { Capabilities }\end{array}$ & Self-belief & $\begin{array}{l}\text { Verbal persuasion } \\
\text { about capability }\end{array}$ \\
\hline
\end{tabular}

At the time of admission, patients are not receptive to new information.

$\begin{array}{lll}\begin{array}{l}\text { Patients who } \\ \text { are in mental }\end{array} & \begin{array}{l}\text { Environmental } \\ \text { Context and }\end{array} & \begin{array}{l}\text { Antecedents, } \\ \text { Associations }\end{array} \\ \text { not be may } & \text { Resources } & \\ \text { cognitively able } & & \\ \text { to understand } & & \\ \text { rights } & & \\ \text { information. } & \end{array}$

Restructuring the social environment; Adding objects to the environment

\section{Proposed intervention}

Training for clinicians about the Mental Health Act and rights notification, with an opportunity to practise in the training
An open legal resource for clinicians and patients

Regular group sessions about rights for patients

Training for clinicians about the Mental Health Act and rights notification, with an opportunity to practise in the training

\begin{tabular}{llll}
$\begin{array}{l}\text { Clinicians don't } \\
\text { believe patients } \\
\text { will understand } \\
\text { the rights } \\
\text { information. }\end{array}$ & Optimism & Self-belief & $\begin{array}{l}\text { Mental rehearsal } \\
\text { of successful } \\
\text { performance }\end{array}$ \\
$\begin{array}{l}\text { Clinicians } \\
\text { believe that } \\
\text { giving rights }\end{array}$ & $\begin{array}{l}\text { Beliefs about } \\
\text { Consequences }\end{array}$ & $\begin{array}{l}\text { Comparison } \\
\text { of Outcomes; }\end{array}$ & $\begin{array}{l}\text { Credible source; } \\
\text { Information about } \\
\text { social and }\end{array}$ \\
\hline
\end{tabular}

Page 25/30 


\begin{tabular}{|c|c|c|c|c|c|}
\hline & $\begin{array}{l}\text { information } \\
\text { may further } \\
\text { agitate } \\
\text { patients. }\end{array}$ & & $\begin{array}{l}\text { Natural } \\
\text { Consequences }\end{array}$ & $\begin{array}{l}\text { environmental } \\
\text { consequences; } \\
\text { Anticipated regret }\end{array}$ & \\
\hline \multirow{3}{*}{$\begin{array}{l}\text { The tool used } \\
\text { to } \\
\text { communicate } \\
\text { rights } \\
\text { information to } \\
\text { patients (Form } \\
13 \text { ) is } \\
\text { inadequate. }\end{array}$} & $\begin{array}{l}\text { Form } 13 \text { is } \\
\text { written with } \\
\text { language that } \\
\text { is inappropriate } \\
\text { for involuntary } \\
\text { patients. }\end{array}$ & $\begin{array}{l}\text { Environmental } \\
\text { Context and } \\
\text { Resources }\end{array}$ & $\begin{array}{l}\text { Antecedents, } \\
\text { Associations }\end{array}$ & $\begin{array}{l}\text { Adding objects to } \\
\text { the environment }\end{array}$ & $\begin{array}{l}\text { An improved } \\
\text { rights- } \\
\text { communication } \\
\text { tool offered in } \\
\text { multiple } \\
\text { languages }\end{array}$ \\
\hline & $\begin{array}{l}\text { Clinicians are } \\
\text { not confident in } \\
\text { their ability to } \\
\text { make the } \\
\text { content on } \\
\text { Form } 13 \\
\text { understandable } \\
\text { to patients. }\end{array}$ & $\begin{array}{l}\text { Beliefs about } \\
\text { Capabilities }\end{array}$ & Self-belief & $\begin{array}{l}\text { Mental rehearsal } \\
\text { of successful } \\
\text { performance }\end{array}$ & \multirow[t]{2}{*}{$\begin{array}{l}\text { Training for } \\
\text { clinicians } \\
\text { about the } \\
\text { Mental Health } \\
\text { Act and rights } \\
\text { notification, } \\
\text { with an } \\
\text { opportunity to } \\
\text { practise in the } \\
\text { training }\end{array}$} \\
\hline & $\begin{array}{l}\text { The } \\
\text { bureaucratic } \\
\text { language on } \\
\text { Form } 13 \text { can } \\
\text { cause patients } \\
\text { to mistrust } \\
\text { staff. }\end{array}$ & $\begin{array}{l}\text { Beliefs about } \\
\text { Consequences }\end{array}$ & $\begin{array}{l}\text { Comparison } \\
\text { of Outcomes; } \\
\text { Natural } \\
\text { Consequences }\end{array}$ & Credible source & \\
\hline $\begin{array}{l}\text { Many patients } \\
\text { don't speak } \\
\text { English. }\end{array}$ & $\begin{array}{l}\text { The only } \\
\text { available } \\
\text { written rights } \\
\text { information is } \\
\text { in English and } \\
\text { is not } \\
\text { understandable } \\
\text { to patients who } \\
\text { don't speak } \\
\text { English. }\end{array}$ & $\begin{array}{l}\text { Environmental } \\
\text { Context and } \\
\text { Resources }\end{array}$ & $\begin{array}{l}\text { Antecedents, } \\
\text { Associations }\end{array}$ & $\begin{array}{l}\text { Adding objects to } \\
\text { the environment }\end{array}$ & $\begin{array}{l}\text { An improved } \\
\text { rights- } \\
\text { communication } \\
\text { tool offered in } \\
\text { multiple } \\
\text { languages }\end{array}$ \\
\hline \multirow[t]{2}{*}{$\begin{array}{l}\text { Clinicians have } \\
\text { many } \\
\text { competing } \\
\text { priorities in the } \\
\text { admission } \\
\text { process, which } \\
\text { can be busy } \\
\text { and chaotic. }\end{array}$} & $\begin{array}{l}\text { The chaos and } \\
\text { workload } \\
\text { involved in the } \\
\text { admission } \\
\text { process is an } \\
\text { environmental } \\
\text { stressor for } \\
\text { clinicians. }\end{array}$ & $\begin{array}{l}\text { Environmental } \\
\text { Context and } \\
\text { Resources }\end{array}$ & $\begin{array}{l}\text { Antecedents, } \\
\text { Associations }\end{array}$ & $\begin{array}{l}\text { Prompts/cues; } \\
\text { Adding objects to } \\
\text { the environment }\end{array}$ & \multirow[t]{2}{*}{$\begin{array}{l}\text { Checklists, } \\
\text { reminders, and } \\
\text { accountability } \\
\text { and feedback } \\
\text { systems }\end{array}$} \\
\hline & $\begin{array}{l}\text { Giving patients } \\
\text { rights } \\
\text { information is } \\
\text { not a } \\
\text { prominent part } \\
\text { of clinician's } \\
\text { perceptions of } \\
\text { their } \\
\text { professional } \\
\text { role. }\end{array}$ & $\begin{array}{l}\text { Social/ } \\
\text { Professional } \\
\text { Role }\end{array}$ & No BCTs & & \\
\hline $\begin{array}{l}\text { Clinicians face } \\
\text { pressure from } \\
\text { other staff not } \\
\text { to give rights } \\
\text { information in }\end{array}$ & $\begin{array}{l}\text { If patients } \\
\text { request a } \\
\text { review panel } \\
\text { hearing, the } \\
\text { physician must }\end{array}$ & $\begin{array}{l}\text { Social } \\
\text { Influences }\end{array}$ & $\begin{array}{l}\text { Comparison } \\
\text { of Behaviour; } \\
\text { Social } \\
\text { Support }\end{array}$ & $\begin{array}{l}\text { Demonstration of } \\
\text { the behaviour; } \\
\text { Social support }\end{array}$ & $\begin{array}{l}\text { Training for } \\
\text { clinicians } \\
\text { about the } \\
\text { Mental Health } \\
\text { Act and rights }\end{array}$ \\
\hline
\end{tabular}


an understandable way. take time to

prepare for the

hearing;

therefore, they

may not want

patients to be

fully informed

of that right.

\section{Having}

clinicians give

rights

information to

the people they

are detaining

presents a

conflict of

interest.

The clinical

workflow

doesn't

facilitate

follow-up and

accountability.

There is no formal way to communicate among staff whether a patient has received and has understood information about their rights.

\begin{tabular}{|c|c|c|c|}
\hline $\begin{array}{l}\text { The } \\
\text { organizational } \\
\text { culture has not } \\
\text { encouraged } \\
\text { staff to } \\
\text { develop } \\
\text { systems to } \\
\text { prioritize rights } \\
\text { information. }\end{array}$ & $\begin{array}{l}\text { Social } \\
\text { Influences }\end{array}$ & $\begin{array}{l}\text { Comparison } \\
\text { of Behaviour; } \\
\text { Social } \\
\text { Support }\end{array}$ & $\begin{array}{l}\text { Demonstration of } \\
\text { the behaviour; } \\
\text { Social support }\end{array}$ \\
\hline
\end{tabular}

\section{Environmental Antecedents, Restructuring the An open legal Context and Associations Resources social environment; Adding objects to \\ resource for clinicians and patients} the environment notification, with an opportunity to practise in the training
Regular group sessions about rights for patients

\begin{tabular}{|c|c|c|}
\hline $\begin{array}{l}\text { Environmental } \\
\text { Context and } \\
\text { Resources }\end{array}$ & $\begin{array}{l}\text { Antecedents, } \\
\text { Associations }\end{array}$ & $\begin{array}{l}\text { Prompts/cues; } \\
\text { Adding objects to } \\
\text { the environment }\end{array}$ \\
\hline
\end{tabular}

Checklists, reminders, and accountability and feedback systems
Training for clinicians about the Mental Health Act and rights notification, with an opportunity to practise in the training

An open legal resource for clinicians and patients

that patients

understand

their leads to a

lack of

accountability.

\begin{tabular}{|c|c|c|}
\hline \multirow[t]{2}{*}{$\begin{array}{l}\text { The } \\
\text { organization } \\
\text { doesn't give } \\
\text { staff enough } \\
\text { resources and } \\
\text { support. }\end{array}$} & $\begin{array}{l}\text { There is often } \\
\text { not enough } \\
\text { staff to ensure } \\
\text { that rights } \\
\text { information is } \\
\text { consistently } \\
\text { and completely } \\
\text { given to } \\
\text { patients. }\end{array}$ & $\begin{array}{l}\text { Environmental } \\
\text { Context and } \\
\text { Resources }\end{array}$ \\
\hline & $\begin{array}{l}\text { When there is a } \\
\text { shortage of } \\
\text { staff, clinicians } \\
\text { prioritize other }\end{array}$ & $\begin{array}{l}\text { Social/ } \\
\text { Professional } \\
\text { Role }\end{array}$ \\
\hline
\end{tabular}


clinical duties

over giving

rights

information

because they

are socialized

to a

paternalistic

system.

\section{FACILITATORS}

\begin{tabular}{|c|c|c|c|c|c|}
\hline $\begin{array}{l}\text { Facilitator } \\
\text { (theme) }\end{array}$ & Subtheme & Domain & $\begin{array}{l}\text { Behaviour } \\
\text { change } \\
\text { technique } \\
\text { grouping }\end{array}$ & $\begin{array}{l}\text { Behaviour change } \\
\text { techniques }\end{array}$ & $\begin{array}{l}\text { Proposed } \\
\text { intervention }\end{array}$ \\
\hline
\end{tabular}

\begin{tabular}{|c|c|c|}
\hline $\begin{array}{l}\text { A team } \\
\text { approach } \\
\text { allows } \\
\text { clinicians to } \\
\text { learn from one } \\
\text { another about } \\
\text { the Mental }\end{array}$ & $\begin{array}{l}\text { Staff remind } \\
\text { one another of } \\
\text { their } \\
\text { responsibility } \\
\text { to give patients } \\
\text { rights } \\
\text { information. }\end{array}$ & $\begin{array}{l}\text { Social/ } \\
\text { Professional } \\
\text { Role }\end{array}$ \\
\hline
\end{tabular}

Health Act and about the rightsnotification process.

$\begin{array}{llll}\text { Newer staff } & \text { Social } & \begin{array}{l}\text { Comparison } \\ \text { of Bearn to fulfill }\end{array} & \begin{array}{l}\text { Demonstration of } \\ \text { Influences }\end{array} \\ \text { the behaviour }\end{array}$

Training for clinicians about rights notification by experienced clinicians, with an opportunity to practise in the training

their rights-

notification

responsibilities

from more

experienced

staff.

Having one
person take
responsibility
for rights
information
clarifies
clinicians' roles
and increases
accountability.

Assigning one

Social/ No BCTs

person the Professional

No BCTs

Checklists, responsibility Role

of giving rights

information

makes that

task part of

their

professional

role.

\begin{tabular}{|c|c|c|c|c|}
\hline $\begin{array}{l}\text { Having a } \\
\text { clearly defined } \\
\text { role reinforces } \\
\text { that staff } \\
\text { member's } \\
\text { intention to } \\
\text { give rights } \\
\text { information } \\
\text { consistently. }\end{array}$ & Intentions & $\begin{array}{l}\text { Goals and } \\
\text { Planning }\end{array}$ & $\begin{array}{l}\text { Goal setting; } \\
\text { Action planning; } \\
\text { Review outcome } \\
\text { goals; } \\
\text { Commitment }\end{array}$ & \\
\hline $\begin{array}{l}\text { The } \\
\text { accreditation } \\
\text { process } \\
\text { reminded staff } \\
\text { of their } \\
\text { responsibility } \\
\text { to give rights } \\
\text { information to } \\
\text { patients. }\end{array}$ & $\begin{array}{l}\text { Social/ } \\
\text { Professional } \\
\text { Role }\end{array}$ & No BCTs & & $\begin{array}{l}\text { Checklists, } \\
\text { reminders, and } \\
\text { accountability } \\
\text { and feedback } \\
\text { systems }\end{array}$ \\
\hline
\end{tabular}

Accreditation processes

remind

clinicians of

the importance

of giving rights

information to

involuntary

patients. reminders, and accountability and feedback systems 


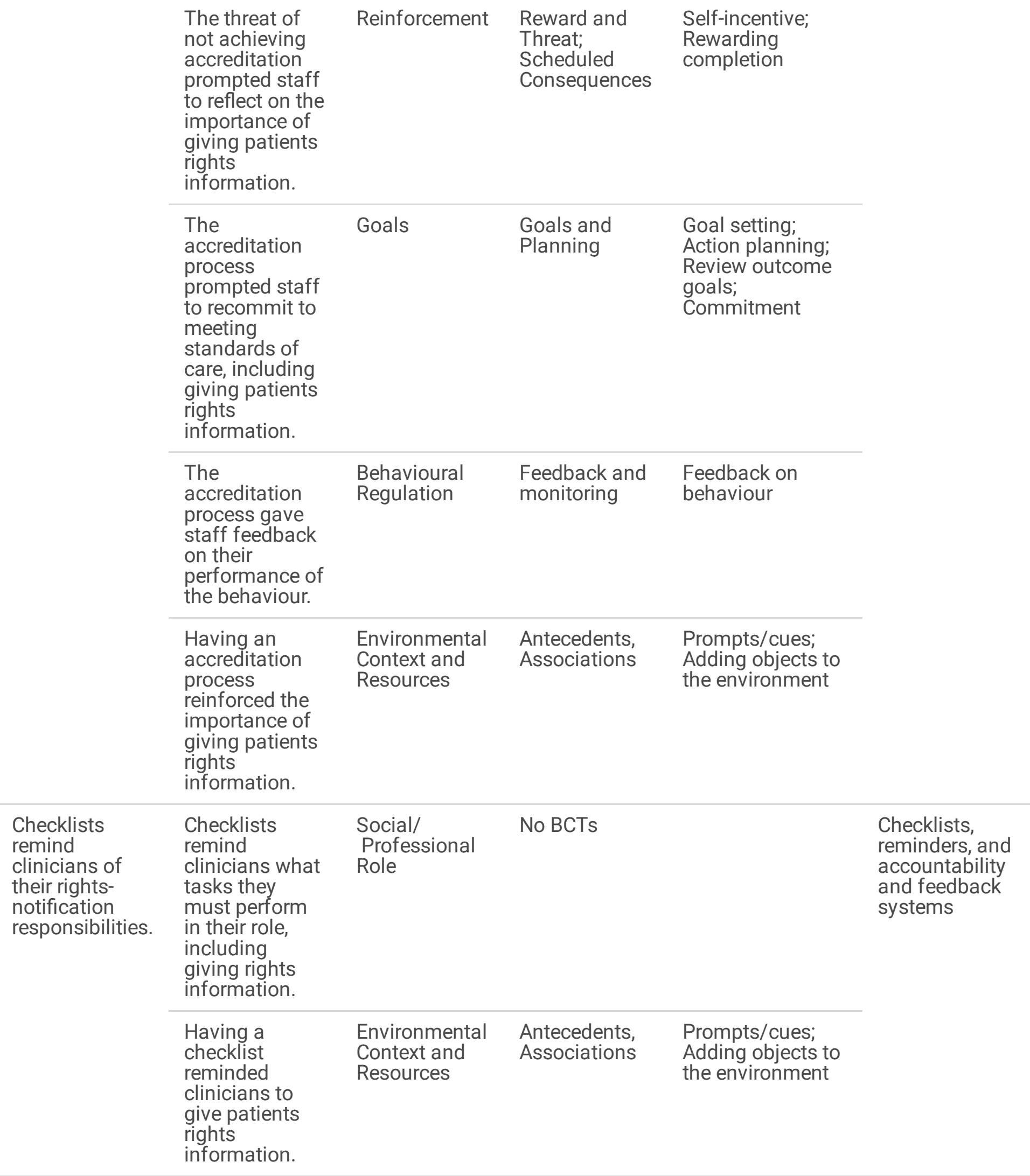

HYPOTHETICAL FACILITATORS

\begin{tabular}{|llllll|}
$\begin{array}{l}\text { Hypothetical } \\
\text { facilitator } \\
\text { (theme) }\end{array}$ & Subtheme & Domain & $\begin{array}{l}\text { Behaviour } \\
\text { change } \\
\text { technique } \\
\text { grouping }\end{array}$ & $\begin{array}{l}\text { Behaviour change } \\
\text { techniques }\end{array}$ & $\begin{array}{l}\text { Proposed } \\
\text { intervention }\end{array}$ \\
\hline A legal or & Clinicians often & Knowledge & Shaping & Instruction on & An open legal
\end{tabular}




\begin{tabular}{|c|c|c|c|c|c|}
\hline \multirow[t]{3}{*}{$\begin{array}{l}\text { advocacy } \\
\text { service that } \\
\text { clinicians could } \\
\text { contact with } \\
\text { questions } \\
\text { about the } \\
\text { Mental Health } \\
\text { Act would } \\
\text { allow clinicians } \\
\text { to better help } \\
\text { patients } \\
\text { exercise their } \\
\text { rights. }\end{array}$} & $\begin{array}{l}\text { have legal } \\
\text { questions } \\
\text { about the } \\
\text { Mental Health } \\
\text { Act, either } \\
\text { amongst } \\
\text { themselves or } \\
\text { from } \\
\text { patients, that } \\
\text { they don't know } \\
\text { how to answer. }\end{array}$ & & knowledge & $\begin{array}{l}\text { how to perform a } \\
\text { behaviour }\end{array}$ & \multirow[t]{3}{*}{$\begin{array}{l}\text { resource for } \\
\text { clinicians and } \\
\text { patients }\end{array}$} \\
\hline & $\begin{array}{l}\text { A legal } \\
\text { resource may } \\
\text { fulfill the } \\
\text { function of a } \\
\text { legal advisor } \\
\text { that clinicians } \\
\text { feel ill } \\
\text { equipped to } \\
\text { perform. }\end{array}$ & $\begin{array}{l}\text { Social/ } \\
\text { Professional } \\
\text { Role }\end{array}$ & No BCTs & & \\
\hline & $\begin{array}{l}\text { Having } \\
\text { answers to } \\
\text { their legal } \\
\text { questions } \\
\text { without } \\
\text { clinicians' } \\
\text { having to worry } \\
\text { about paying } \\
\text { legal fees } \\
\text { would allow } \\
\text { staff to better } \\
\text { help patients } \\
\text { exercise their } \\
\text { rights. }\end{array}$ & $\begin{array}{l}\text { Environmental } \\
\text { Context and } \\
\text { Resources }\end{array}$ & Antecedents & $\begin{array}{l}\text { Adding objects to } \\
\text { the environment }\end{array}$ & \\
\hline $\begin{array}{l}\text { Regular, open } \\
\text { information } \\
\text { sessions for } \\
\text { patients would } \\
\text { give them } \\
\text { opportunities } \\
\text { to learn about } \\
\text { their rights } \\
\text { when they are } \\
\text { ready to receive } \\
\text { the } \\
\text { information. }\end{array}$ & $\begin{array}{l}\text { Patients are } \\
\text { more likely to } \\
\text { be receptive to } \\
\text { the information } \\
\text { if it is given } \\
\text { outside of the } \\
\text { busy, chaotic } \\
\text { context of an } \\
\text { admission and } \\
\text { if they are able } \\
\text { to seek out the } \\
\text { information } \\
\text { themselves. }\end{array}$ & $\begin{array}{l}\text { Environmental } \\
\text { Context and } \\
\text { Resources }\end{array}$ & $\begin{array}{l}\text { Antecedents, } \\
\text { Associations }\end{array}$ & $\begin{array}{l}\text { Restructuring the } \\
\text { social } \\
\text { environment; } \\
\text { Adding objects to } \\
\text { the environment }\end{array}$ & $\begin{array}{l}\text { Regular group } \\
\text { sessions about } \\
\text { rights for } \\
\text { patients }\end{array}$ \\
\hline
\end{tabular}

